\title{
POLITIK HUKUM MENEGAKKAN KONSTITUSI Tinjauan Status Dwi Kewarganegaraan Berdasarkan Undang-Undang No. 12 Tahun 2006
}

Oleh :

\author{
Nurlely Darwis, SH, MSi \\ Dosen Tetap Fakultas Hukum Universitas Dirgantara Marsekal Suryadarma Jakarta. \\ Kandidat Doktor Ilmu Hukum \\ Email : (nurlely.darwis@gmail.com)
}

\begin{abstract}
Abstrak:
Indonesian political spirit of citizenship law is to ensure the ownership status of citizens for everyone, but exclusively a fixed priority to the interests of the nation and the people of Indonesia. And that is why Indonesia is adopting a single citizenship with dual-citizenship tolerance is limited.

That translated into legal politics of Indonesian nationalism nationality Indonesia at that time. Even if nationalism is now regarded as no longer relevant and needs to be repaired again, of course it can be done, because the law is an agreement or in other words the resultant of every situation and condition.

Semangat politik hukum kewarganegaraan Indonesia adalah menjamin kepemilikan status warga negara bagi setiap orang, tetapi secara eksklusif tetap mengutamakan kepentingan bangsa dan rakyat Indonesia. Maka oleh karena itu Indonesia menganut sistem kewarganegaraan tunggal dengan toleransi dwi-kewarganegaraan secara terbatas.

Itulah terjemahan nasionalisme Indonesia kedalam politik hukum kewarga-negaraan Indonesia pada masa itu. Kalaulah nasionalisme yang seperti ini sekarang dianggap sudah tidak relevan dan perlu diperbaiki lagi, tentu saja hal itu bisa dilakukan, sebab hukum adalah kesepakatan atau dengan kata lain hasil dari setiap perkembangan situasi dan kondisi.
\end{abstract}

\section{Pendahuluan}

Apabila melihat dan mencermati situasi dan kondisi aktual saat ini, tampak bahwa kehidupan bermasyarakat, berbangsa dan bernegara sedang menghadapi suatu cobaan yang sangat berat, yaitu Krisis Multidimensi diseluruh aspek kehidupan nasional. Situasi dan kondisi tersebut disebabkan oleh globalisasi yang dapat mempengaruhi pola pikir, pola sikap dan pola tindak masyarakat. Yan mana hal ini akan mempengaruhi kondisi mental spiritual bangsa Indonesia.

Menghadapi kondisi tersebut, pada dasarnya bangsa ini harus sama-sama melihat kebelakang untuk mencermati sejarah perjuangan bangsa Indonesia. Pada waktu merebut dan mempertahankan kemerdekaan, bangsa Indonesia berjuang dengan 
semangat kebangsaan yang tinggi yang dilandasi oleh iman dan ketaqwaan kepada Tuhan Yang Maha Esa serta sikap ikhlas berkorban. Semangat tersebut merupakan kekuatan mental spiritual yang dapat melahirkan sikap dan perilaku yang "Heroic dan Patriotik" sebagai modal untuk merebut kemerdekaan sehingga melahirkan Negara Kesatuan Republik Indonesia.

Meskipun Dihadapkan pada berbagai tantangan sejak Indonesia Merdeka, Negara Kesatuan RI tetap tegak sebagai satu negara yang berdaulat, yang menunjukan bahwa Negara RI bukanlah Negara Absolut, melainkan Negara hukum dengan penyelenggaraan pemerintahan atas dasar Hukum dan Kekuasaan Kehakiman dengan sifat Demokrasi. Dalam perjuangan tersebut untuk mempertahankan Negara Kesatuan RI inilah yang disebut sebagai "Ketahanan Nasional", atas dasar Manusia yang Berbudaya untuk mencapai Tujuan Nasional, atas dasar falsafah bangsa dan Ideologi Negara.

Pengertian Ketahanan Nasional Indonesia, dalam Pengertian yang baku adalah: "Kondisi dinamis bangsa Indonesia yang meliputi segenap aspek kehidupan Nasional yang terintegrasi, dan berisi keuletan dan ketangguhan yang mengandung kemampuan untuk mengembangkan kekuatan nasional dalam menghadapi segala tantangan dan ancaman, hambatan dari dalam maupun luar guna mencapai tujuan nasional". Selanjutnya konsepsi Ketahanan Nasional Indonesia adalah "Konsepsi pengembangan kekuatan nasional melalui pengaturan dan penyelenggaraan kesejahteraan dan Keamanan yang seimbang, serasi, dan selaras dalam seluruh aspek kehidupan berdasarkan Pancasila".

Asas - asas Ketahanan Nasional Indonesia, adalah tata laku berdasarkan nilai- nilai Pancasila, UUD-45 dan wawasan nusantara yang terdiri dari asas kesejahteraan dan keamanan, asas komprehensif integral atau menyeluruh terpadu, asas mawas kedalam dan Keluar, asas kekeluargaan. Sifat Ketahanan Nasional Indonesia, adalah sifat yang terbentuk dari nilai-nilai yang terkandung dalam landasan dan asasasasnya yaitu asas Mandiri, Independensi, Dinamis (berarti ia dapat meningkat dan menurun). Wibawa dalam arti makin tinggi tingkat daya tangkal maka makin tinggi kewibawaan bangsa, konsultasi dan kerjasama dalam arti lebih mengutamakan sikap konsultatif, kerjasama, saling menghargai dengan mengandalkan kekuatan moral dan kepribadian bangsa.

$\begin{array}{cr}\text { Pengaruh } & \text { aspek } \\ \text { Nasional terhadap } & \text { kehidupan }\end{array}$ berbangsa dan bernegara, adalah menyangkut pada tata kehidupan nasional yang berhubungan antara manusia dengan manusia, manusia dengan Tuhan, manusia dan masyarakat, manusia dan lingkungan antara lain, (1).Pengaruh Aspek Ideologi, Ideologi Dunia dan Ideologi Pancasila; (2).Pengaruh Aspek Politik, Politik Secara Umum, Politik Indonesia ( Politik dalam Negeri dan Politik Luar Negeri); (3).Pengaruh Aspek Ekonomi, Ekonomi secara umum, Perekonomian Indonesia; (4).Pengaruh Aspek Sosial Budaya; 
(5).Pengaruh Aspek Pertahanan dan Keamanan.

Untuk mengisi kemerdekaan dan mengatasi krisis multi dimensional dalam kehidupan bermasyarakat, berbangsa dan bernegara, diharapkan seluruh anak bangsa untuk bersamasama mengabdi dan membela Negara yang dicintai ini dengan semangat kebangsaan dan semangat "Nasionalisme". Pada jamannya semangat perjuangan bangsa dilakukan dengan perjuangan fisik, sedangkan dalam era globalisasi kini dan untuk mengisi kemerdekaan bangsa tentu dilaksanakan dengan perjuangan Non Fisik sesuai dengan bidang profesi masing - masing.

Bahan ajar Pendidikan Kewarganegaraan sebagai bagian dari kurikulum pendidikan di tiap tingkat pendidikan diharapkan akan memuat pengetahuan dan kemampuan dasar warga-negara berkenaan dengan hubungan antara warga-negara dan Negara agar mereka memiliki wawasan kesadaran berbangsa dan bernegara dengan tebalnya rasa nasionalisme demi tetap tegaknya Negara Kesatuan Republik Indonesia. Jadi tujuan utama pendidikan Kewarganegaraan dalam hal ini adalah untuk menumbuhkan rasa nasionalisme yang kuat melalui wawasan dan kesadaran bernegara, sikap serta perilaku yang cinta tanah air dan bersendikan kebudayaan bangsa, wawasan nusantara, serta Ketahanan Nasional.

Tentang siapakah warga-negara itu, hal ini ada dinyatakan dalam pasal 26 ayat (1) Undang-Undang dasar Negara Kesatuan RI. 1945 bahwa: "yang menjadi Warga-Negara adalah orang-orang bangsa Indonesia asli dan orang - orang bangsa lain yang disahkan dengan undang-undang sebagai warga negara". Selanjutnya pada ayat (2) menjelaskan syaratsyarat mengenai kewarganegaraan ditetapkan dengan undang - undang.

Peran warga-negaraan dari sudut pandang konsep demokrasi adalah rakyat beserta warga masyarakat didefinisikan sebagai Warga-Negara. Demokrasi adalah sebuah bentuk kekuasaan (kratein) dari dan oleh dan untuk rakyat (demos). ${ }^{1}$ Jadi menurut konsep demokrasi, kekuasaan menyiratkan arti politik dan pemerintahan, sedang setiap negara mempunyai ciri khas dalam pelaksanaan kedaulatan rakyat atau demokrasinya. Hal ini ditentukan oleh sejarah negara yang bersangkutan, kebudayaan pandangan hidup, serta tujuan yang ingin dicapainya. Konsep demokras sebagai "Kedaulatan Rakyat" bertumpu pada prinsip, bahwa rakyat secara keseluruhan dipandang sebagai pemegang kedaulatan politik. Rakyat merupakan sumber utama kekuasaan, kewenangan, dan kepentingan, sehingga kesejahteraan rakyat adalah tujuan utama bagi para penguasa politik dan pemerintah.

\section{Permasalahan}

Undang-Undang No. 12 tahun 2006 tentang Kewarganegaraan Republik Indonesia telah genap berusia satu dekade pada 1 Agustus 2016 yang lalu. Usia yang sesungguhnya belum dapat dikatakan

1 H.A. Prayitno, Trubus MS; Pendidikan KADEHAM, Kebangsaan, Demokrasi, dan Hak Asasi Manusia; hlm, 116. 
panjang untuk ukuran berlakunya sebuah undang - undang.

Keberadaan UU No. 12 tahun 2006 itu telah berhasil mengantarkan bangsa ini keluar dari persoalan diskriminatif, kurang menjamin hakhak asasi manusia, kesetaraan, serta perlindungan perempuan dan anak. Karena tidak ada lagi surat bukti kewarganegaraan RI untuk etnik Tionghoa. Dalam hal ini harus tegas dikatakan bahwa sebuah undangundang yang baik harus mampu mengakomodasi perkembangan yang begitu cepat.

UU 12 tahun 2006 belum sepenuhnya mengantisipasi perkembangan zaman, karena beberapa waktu lalu ternyata ada dua kasus mengemuka terkait dengan kewarganegaraan, yaitu Presiden Joko Widodo memberhentikan dengan hormat Arcandra Tahar dari jabatan menteri energi dan sumber daya mineral karena yang bersangkutan memegang paspor Amerika Serikat dan Indonesia.

\begin{tabular}{llr}
\multicolumn{1}{c}{ Keputusan } & $\begin{array}{c}\text { Presiden } \\
\text { sebatut } \\
\text { diapresiasi }\end{array}$ & sentuk \\
pelaksanaan & UU Kewarganegaraan
\end{tabular}
yang menganut asas kewarganegaraan tunggal, satu kewarganegaraan bagi setiap orang. Berikutnya ada kasus Gloria Natapradja Hamel yang tidak jadi dikukuhkan sebagai anggota Paskibraka meski telah mengikuti proses seleksi dan latihan berbulanbulan, karena remaja ini diketahui ada memiliki paspor Prancis sebab ayahnya warga negara Prancis meski ibunya warga negara Indonesia. Kasus Gloria, ini untuk kewarganegaraanya dia diharuskan untuk di daftarkan ke institusi yang ditunjuk guna mendapatkan kewarganegaraan Indonesia.

Meskipun Undang - Undang Kependudukan memberi peluang untuk dwikewarganegaraan sampai anak usia 18 tahun, namun ada aturan orangtua harus mendaftarkan anaknya paling lambat empat tahun sesudah UU Kewarganegaraan diberlakukan. Dua kasus ini seharusnya menjadi dasar pertimbangan apakah masih perlu Indonesia mempertahankan asas kewarganegaraan tunggal?

Hingga saat ini, ada 56 negara di dunia yang telah menyesuaikan kebijakan imigrasi dan kewarganegaraan untuk mengakomodasi diaspora. ${ }^{2}$ Setidaknya, ada 44 negara telah menerapkan kebijakan dwikewarganegaraan, yang berarti seseorang tidak kehilangan kewarganegaraan negara asal apabila mengambil kewarganegaraan negara lain. ${ }^{3}$

\section{Politik Hukum dan Nasionalisme} Warga-Negara

Pembangunan hukum yang mencakup upaya-upaya pembaharuan tatanan hukum di Indonesia pada dasarnya harus dilakukan secara terus menerus agar hukum dapat

${ }^{2}$ Diaspora Indonesia menurut https://id.wikipedia.org/wiki/; Diaspora atau orang Indonesia perantauan adalah orang-orang Indonesia yang menetap di luar Indonesia. Istilah ini berlaku bagi orang-orang yang lahir di Indonesia dan berdarah Indonesia yang menjadi warga negara tetap ataupun menetap sementara di negara asing.

3

http://mediaindonesia.com/news/read/62120/dwi kewarganegaraan-bisa-untungkan-indonesia/201608-18. 
memainkan peran dan fungsinya sebagai pedoman bertingkah laku (fungsi ketertiban) dalam hidup bersama yang imperatif dan efektif sebagai penjamin keadilan di dalam masyarakat. Upaya terus menerus ini dilakukan atas dasar tiga alasan yaitu: ${ }^{4}$ Pertama: Sebagai pelayan bagi masyarakat, karena hukum itu tidak berada pada kevakuman. Maka hukum harus senantiasa disesuaikan dengan perkembangan masyarakat yang dilayaninya; Kedua: Sebagai alat pedorong kemajuan masyarakat; Ketiga: karena secara realitas di Indonesia saat ini fungsi hukum tidak bekerja efektif, sering dimanipulasi, bahkan jadi alat (instrumen efektif) bagi penimbunan kekuasaan.

Upaya pembaharuan tata hukum itu haruslah tetap menjadikan Pancasila sebagai paradigma, sebab Pancasila berkedudukan sebagai dasar, ideologi, cita hukum dan norma fundamental negara. Oleh sebab itu harus dijadikan orientasi arah, sumber nilai-nilai dan karenanya juga merupakan kerangka berfikir dalam setiap upaya pembaharuan hukum.

Mengingat tidak efektifnya hukum dalam memainkan peran dan fungsinya di Indonesia saat ini bukan disebabkan oleh tidak layaknya Pancasila sebagai paradigma, tetapi sebaliknya disebabkan oleh penyimpangan dari paradigma Pancasial itu. Dan hal yang banyak muncul adalah tuntutan agar kehidupan hukum ditata kembali

4 Moh. Mahfud MD; Membangun Politik Hukum Mengegakkan Konstitusi; Rajawali Pers; Divisi Buku Perguruan Tinggi, PT Raja Grafindo Persada, Jakarta 2012; hlm. 62 sesuai dengan nilai-nilai Pancasila sebagai paradigmanya dan dapat menyentuh Undang-Undang Dasar Negara Kesatuan Republik Indonesia 1945 sebagai hukum dasar dan semua peraturan perundang - undangan yang ada dibawahnya. ${ }^{5}$

Berkaitan dengan Nasionalisme dan Status Dwi Kewarganegaraan, lalu orang sibuk mengusulkan agar segera melakukan revisi UndangUndang No. 12 Tahun 2006 Tentang Kewarganegaraan. Pertanyaan kemudian adalah apa sebenarnya yang dimasudkan dengan Nasionalisme bagi seorang warganegara.

Pemahaman umum "Nasionalisme Indonesia" adalah suatu gerakan kebangsaan yang timbul pada bangsa Indonesia untuk menjadi sebuah bangsa yang merdeka dan berdaulat. Dari sejarah yang ada, sejak abad 19 dan abad 20 muncul benih-benih nasionalisme pada bangsa Asia Afrika khusus Indonesia. ${ }^{6}$ Kenangan kejayaan masa lampau tampak dengan adanya kenangan akan kejayaan pada masa kerajaan Majapahit dan Sriwijaya.

Dimana pada masa Majapahit, mereka mampu menguasai daerah seluruh Nusantara, sedangkan masa Sriwijaya mampu berkuasa di lautan karena maritimnya yang kuat.

Paham nasionalis memang berkembang dalam bidang politik, sosial ekonomi, dan kebudayaan dan salah satunya adalah dalam bidang

\section{${ }^{5}$ Ibid.}

https://id.wikipedia.org/wiki/Nasionalisme_Indon esia 
budaya yaitu tampak dengan upaya untuk melindungi, memperbaiki dan mengembalikan budaya bangsa Indonesia yang hampir punah karena masuknya budaya asing di Indonesia akibat era globalisasi. Para nasionalis berusaha untuk memperhatikan dan menjaga serta menumbuhkan kebudayaan asli bangsa Indonesia dalam hal cinta tanah air.

Memahami Politik Hukum pada dasarnya harus melihat antara Politik dan Hukum yang merupakan dua topik ilmu dengan ranah yang berbeda. Melihat hukum yang dapat dipelajari dari berbagai sudut pandang, maka lahirlah berbagai disiplin hukum seperti Filsafat Hukum, Ilmu Hukum, Teori Hukum, Sejarah Hukum, Sosiologi Hukum, Perbandingan Hukum, Logika Hukum, Psikologi hukum, dan selanjutnya ada Politik Hukum (Rechtspolitiek). Politik Hukum adalah suatu bidang ilmu yang mempunyai ciri-ciri tertentu, yaitu kegiatan untuk menentukan atau memilih hukum mana yang sesuai untuk mencapai tujuan-tujuan yang dikehendaki oleh masyarakat. $^{7}$

Antara kedua topik yang berbeda itu ternyata mempunyai sifat yang saling mempengaruhi. Pada tataran realitas kedua topik tersebut kadangkadang menunjukkan bahwa hukum dapat mempengaruhi politik atau sebaliknya politik dapat mempengaruhi hukum. Moh Mahfud MD mengemukakan tentang hal tersebut bahwa terdapat tiga macam jawaban untuk melihat hubungan antara hukum dan politik: Pertama, hukum merupakan determinan politik, kegiatan politik harus tunduk pada hukum; Kedua, pandangan yang melihat bahwa politik determinan atas hukum karena sesungguhnya hukum adalah produk politik yang sarat dengan kepentingan dan konfigurasi politik; dan ketiga pandangan yang melihat bahwa hukum dan politik merupakan dua elemen subsistem kemasyarakatan yang seimbang, karena walaupun hukum merupakan produk politik maka ketika ada hukum yang mengatur aktivitas politik maka politikpun harus tunduk pada hukum. $^{8}$

Ketiga macam jawaban di atas adalah bangunan teori yang dibangun berdasarkan realitas relasi antara dua sistem tersebut. Pada kesimpulan akhir tulisannya Mahfud MD menyimpulkan bahwa sesungguhnya politik determinan atas hukum, hukum yang lahir merupakan cerminan konfigurasi politik. Dalam hubungan tarik menarik antara hukum dan politik maka sesungguhnya politik mempunyai energi yang cukup kuat untuk mempengaruhi hukum. Asumsi dasar tadi memperlihatkan bahwa dalam konfigurasi politik yang demokratis maka yang lahir adalah produk hukum yang responsif/populistik, sedangkan konfigurasi politik yang otoriter melahirkan produk hukum yang konservatif /ortodoks dan elitis. ${ }^{9}$
${ }^{7}$ Satjipto Rahardjo, Ilmu Hukum; Alumni, Bandung; 1991, hlm 325; Melalui buku Imam Syaukani; A. Ahsin Thohari; Dasar-Dasar Politik Hukum, PT Raja Grafindo Persada, Jakarta; hlm.2.

\footnotetext{
${ }^{8}$ Imam Syaukani; A. Ahsin Thohari; DasarDasar Politik Hukum, PT Raji Grafindo Persada, Jakarta; hlm.5 - 8

${ }^{9}$ Ibid.hlm. 7 - 8
} 
Ada beberapa ahli hukum mendefinisikan Politik Hukum seperti Padmo Wahyono, Teuku Mohammad Radhie, Soedarto, Satjipto Rahardjo, Sunaryati Hartono, dan Abdul Hakim Garuda Nusantara. Dalam hal ini yang menarik adalah pendapat dari Satjipto Rahardjo yang mendefinisikan Politik Hukum sesuai dengan keahliannya dibidang Sosiologi, dengan begitu penyataannya menjelaskan bahwa politik hukum digunakan untuk mencapai suatu tujuan sosial dan hukum tertentu dalam masyarakat. ${ }^{10}$

Berkaitan dengan Politik Hukum Nasional, tinjauan awalnya adalah memahami pengertian politik hukum yang diartikan sebagai, "Kebijakan dasar penyelenggara negara dalam bidang hukum yang akan, sedang dan telah berlaku, yang bersumber dari nilai-nilai yang berlaku di masyarakat untuk mencapai tujuan negara yang dicita-citakan". Jadi Politik Hukum Nasional adalah, Kebijakan dasar penyelenggara negara dalam bidang hukum yang akan, sedang dan telah berlaku, yang bersumber dari nilainilai yang berlaku di masyarakat untuk mencapai tujuan (Republik Indonesia) negara yang dicitacitakan. ${ }^{11}$

Sejalan dengan pernyataan dari A.H.G. Nusantara, bahwa dalam konteks politik Hukum, jelas bahwa hukum adalah "alat" yang bekerja dalam "Sistem Hukum" tertentu untuk mencapai "tujuan" negara atau cita-cita masyarakat Indonesia sebagaimana terumuskan dalam pembukaan UUD-1945, meliputi: ${ }^{12}$

1. Melindungi segenap bangsa dan seluruh tumpah darah Indonesia;

2. Memajukan kesejahteraan umum;

3. Mencerdaskan kehidupan bangsa;

4. Ikut melaksanakan ketertiban dunia, berdasarkan kemerdekaan, perdamaian abadi dan keadilan sosial.

Pada dasarnya Hukum berfungsi sebagai perlindungan kepentingan masyarakat, agar kepentingan masyarakat terlindungi. Untuk itu dalam pelaksanaan penegakan hukum ada tiga unsur yang selalu harus diperhatikan, yaitu, kepastian hukum (Rechtssicherheit),

00kemafaatan (Zweckmassigkeit) dan keadilan (Gerechtigkeit). ${ }^{13}$ Sedangkan permasalahan hukum di Indonesia dapat disebabkan oleh beberapa hal diantaranya yaitu sistem peradilannya, perangkat hukumnya, inkonsistensi penegakan hukum, intervensi kekuasaan, maupun perlindungan hukum.

\section{Dilema Penerapan Status Dwi} kewarganegaraan.

Pakar hukum tata negara Jimly Asshiddiqie berpendapat dwikewarganegaraan bisa menguntungkan Indonesia, asalkan

12 Moh. Mahfud MD; Membangun Politik Hukum, Menegakkan Konstitusi; Rajawali Pers; 2012, hlm. 17

${ }^{13}$ Sudikno Mertokusumo; Penemuan Hukum Sebuah Pengantar, Yogyakarta: Liberty,.1999: 145.
${ }^{10}$ Ibid. hlm. 29
${ }^{11}$ Ibid. hlm. 58 
Politik Hukum Menegakkan Konstitusi, Tinjauan Status Dwi

Kewarganegaraan Berdasarkan Undang-Undang No. 12 Tahun 2006

pengakuan dwikewarganegaraan dilakukan secara bilateral dan tidak dengan sembarang negara. Misalnya dengan AS, dwikewarganegaran justru bisa menguntungkan. Dalam hal ini warga negara Indonesia bisa lebih mudah masuk dan diakui di A.S, dan Indonesia juga bisa memanggil pulang sumber daya manusia yang dibutuhkan untuk membangun bangsa.

Dijelaskan Jimly, bahwa banyak diaspora Indonesia di luar negeri yang memiliki kompetensi mumpuni dan bisa diberdayakan di Tanah Air. Karena itu, kerja sama dwikewarganegaraan bisa diarahkan ke negara-negara kantong diaspora. Studi yang digelar "Taskforce" Imigrasi dan Kewarganegaraan pada 2014 menyimpulkan bahwa pemberlakuan dwikewarganegaraan oleh negaranegara berkembang seperti Pakistan, Sri Lanka, Bangladesh, India, dan Filipina berimbas pada meningkatnya gross national product (GNP) negaranegara tersebut. Maka Jimly selanjutnya mengusulkan pemerintah untuk "merevisi" Undang-Undang Nomor 12 Tahun 2006 tentang Kewarganegaraan agar dapat mengakomodasi diaspora Indonesia di luar negeri. ${ }^{14}$

Sisi negatif jika Indonesia terapkan dwi-kewarganegaraan, ${ }^{15}$ dijelaskan

14

http://mediaindonesia.com/news/read/62060/pak ar-dwikewarganegaraan-bisa-untungkan-indonesiaasalkan/2016-08-17.

15

http://mediaindonesia.com/editorial/read/823/me nimbang-revisi-uu-kewarganegaraan/2016-08-18 Menimbang Revisi UU Kewarganegaraan. (dalam acara PrimeTime News Metro TV, Rabu (17/8/2016) malam). oleh Guru Besar Ilmu Hubungan Internasional Universitas Indonesia, Hikmahanto Juwana yang melihat ada banyak sisi negatif jika Indonesia menerapkan dwi kewarganegaraan. Sisi negatif itu di antaranya adalah warga-negara Indonesia di luar negeri seolah memiliki "harga". Hikmahanto mencontohkan pada kasus penculikan dan penyanderaan WNI di Filipina Selatan. Dalam kasus itu, penyandera meminta uang tebusan kepada Indonesia. Jika begitu, Hikmahanto khawatir siapa yang akan bertanggung jawab atas kasus penculikan bila dewikewarganegaraan diterapkan.

Selanjutnya secara ekonomi Hikmahanto juga mengatakan, bahwa dwi-kewarganegaraan mungkin akan bisa dimanfaatkan oleh warga negara Indonesia yang ingin menghindari pajak tinggi di Tanah Air. Mereka akan memilih menjadi warga negara lain yang menerapkan sistem pajak rendah. Dalam hal ini "Merekamereka yang mempunyai uang banyak kemungkinan besar yang akan memanfaatkan dwi kewarganegaraan ini.

Dwi-kewarganegaraan juga dikhawatirkan akan dimanfaatkan warga-negara asing yang ingin menguasai dan memiliki properti di Indonesia. Mereka akan memanfaatkan paspor Indonesia untuk menguasai properti dan kepemilikan tanah di Indonesia. Maka dalam hal ini "Rakyat Indonesia akan semakin sulit mendapatkan tanah, karena mereka berinvestasi dan membuat harga tanah semakin mahal". Maka berkaitan dengan isu status dewi-kewarganegaraan Hikmahanto meminta agar 
pemerintah mengkaji lebih mendalam dan hati-hati dalam hal menerapkan asas dewi-kewarganegaraan. Untuk hal ini pemerintah tidak harus tergesagesa merevisi Undang-Undang Nomor 12 tahun 2006 tentang Kewarganegaraan.

Berkaitan dengan politik hukum dan kepentingan kelompok masyarakat tertentu Ketua "Diaspora Indonesia" Dino Patti Jalal mengatakan, jika pemerintah Indonesia merevisi Undang-Undang Nomor 12 Tahun 2006 tentang kewarganegaraan, pemerintah harus mengutamakan diaspora Indonesia di luar negeri. Dino menjamin pemerintah akan sangat diuntungkan dengan potensi besar diaspora Indonesia di luar negeri. ${ }^{16}$ Mengingat saat ini orang Indonesia di luar negeri ada enam juta orang. Dua juta diantaranya TKI yang ternyata menyumbang Rp13 triliun ke Tanah Air. Selama ini potensi diasopra Indonesia kurang mendapat perhatian dari pemerintah, padahal, pemerintah dapat memanfaatkan keahlian yang dimiliki para diaspora untuk membangun Tanah Air.

Pemerintah dan DPR merupakan dua institusi pemegang otoritas membuat undang-undang, pada prinsipnya sudah harus mulai mempertimbangkan pemberlakuan dwikewarganegaraan dengan melakukan amedemen UU 12 tahun 2006, mengingat rencana amendemen UU 12 tahun 2006 sudah masuk dalam program legislasi nasional

${ }^{16} \mathrm{Ibid}$ (prolegnas) tahun 2015-2019. ${ }^{17}$ Mengingat kemajuan teknologi telah menghilangkan batas-batas tradisional sebuah wilayah. Perpindahan penduduk dalam rangka mencari ilmu pengetahuan dan kesempatan kerja begitu tinggi, dan saat ini ada data menunjukkan sekitar 8 juta WNI dan mantan WNI di luar negeri. Sebanyak $70 \%$ di antara mereka masih berstatus WNI, sedangkan $30 \%$ lagi sudah pindah kewarganegaraan. Meski pindah kewarganegaraan, mereka tetap tidak lelah mencintai Indonesia. Demikian dinyatakan oleh ketua Diaspora.

V. Politik Hukum Dwikewarganegaraan

Moh Mahfud MD Ketua Asosiasi Pengajar Hukum Tata Negara dan Hukum Administrasi Negara (APHTN-HAN) (Ketua MK-RI 2008$2013)^{18}$ ada menjelaskann tentang semangat politik hukum kewarganegaraan Indonesia adalah menjamin kepemilikan status warga negara bagi setiap orang, tetapi secara eksklusif tetap mengutamakan kepentingan bangsa dan rakyat Indonesia. Maka oleh karena itu Indonesia menganut sistem kewarganegaraan tunggal dengan

17

http://mediaindonesia.com/editorial/read/823/me nimbang-revisi-uu-kewarga-negaraan / 2016-08-18

${ }^{18}$ Koransindo;

http://www.idartikel.com/mahfudmd/2016/08/politik-hukum-dwi-warga-negara/ 
toleransi dwi-kewarganegaraan secara terbatas.

Itulah terjemahan nasionalisme Indonesia kedalam politik hukum kewarga-negaraan Indonesia pada masa itu. Kalaulah nasionalisme yang seperti ini sekarang dianggap sudah tidak relevan dan perlu diperbaiki lagi, tentu saja hal itu bisa dilakukan, sebab hukum adalah kesepakatan atau dengan kata lain resultante dari setiap perkembangan situasi dan kondisi. Tapi jangan menunjuk bahwa pembentuk Undang-Undang pada masa dahulu telah gagal memahami situasi tentang tren globalisasi. Pembentuk UU yang dulu telah mendiskusikan dan paham tentang itu tetapi itulah resultante yang dicapai pada saat itu dalam menerjemahkan nasionalisme bangsa Indonesia.

$\begin{array}{clr}\text { Pendapat } & \text { orang yang menilai } \\ \text { bahwa } & \text { pembentuk } & \text { UU }\end{array}$ kewarganegaraan adalah gagal memahami tren perkembangan dunia adalah salah. Sebab sebenarnya pembentuk UU Kewarganegaraan pada saat itu sudah mendiskusikan dengan sangat komprehensif mengenai perkembangan dunia. Namun, akhirnya, demi kedaulatan Indonesia yang seluruh sumber daya alamnya harus dimanfaatkan untuk sebesar-besar kemakmuran rakyat, ditetapkanlah berlakunya sistem kewarganegaraan tunggal dengan toleransi pemberlakuan sistem dwikewarganegaraan secara terbatas.

Batasan selanjutnya adalah bahwa, bagi anak yang lahir dari perkawinan campuran antara orang tua WNI dengan warga negara asing serta bagi pasangan WNI yang melahirkan anak di negara-negara yang menganut sistem Ius Soli, maka si anak diberi toleransi untuk memiliki dua kewarganegaraan sampai usia 18 tahun. Selanjutnya berdasar prinsip kemanusiaan, Indonesia harus memperlakukan semua manusia di bumi untuk memperoleh kewarganegaraan, termasuk di Indonesia. Tapi berdasar paham kebangsaan dan kerakyatan yang juga sangat fundamental di dalam konstitusi Indonesia, hal itu harus di atur secara eksklusif dengan memprioritaskan semua kebijakan, baik kewarganegaraan maupun kepemimpin-negaraan, untuk sebesarbesar kemakmuran rakyat dan kepentingan bangsa Indonesia.

Politik hukum yang demikian dinilai lebih sesuai dengan tujuan Indonesia mendirikan Indonesia merdeka dengan semangat nasionalismenya yang niscaya eksklusif. Jadi dalam hubungan antara asas kemanusiaan dan kebangsaan, 
Indonesia memihak pada kepentingan bangsa.

\section{Penutup}

Meninjau kembali pendapat beberapa pakar yang mengemukakan pemahamannya tentang Politik Hukum di Indonesia, pada prinsipnya adalah bahwa Politik Hukum merupakan aktivitas untuk menentukan suatu pilihan mengenai tujuan dan cara-cara yang hendak dipakai sebagai alat mencapai tujuan hukum dalam masyarakat, dan juga berkaitan dengan kebijaksanaan penyelenggara Negara tentang apa yang dijadikan kriteria untuk menghukumkan sesuatu (menjadikan sesuatu sebagai Hukum). Kebijaksanaan tersebut dapat berkaitan dengan pembentukan hukum dan penerapannya. Demikian juga politik hukum sebagai politik perundang-undangan, berarti menetapkan tujuan dan isi peraturan perundang-undangan, dalam hal ini pengertian politik hukum terbatas hanya pada hukum tertulis saja, berati sebagai kegiatan-kegiatan memilih nilai-nilai dan menerapkan nilai-nilai tersebut.

Seberapa besar pengaruh elit politik terhadap penegakan hukum di Indonesia, isu ini yang menarik untuk dikaji dalam hubungan antara hukum dan politik, yaitu pengaruh politik terhadap penegakan hukum, sebab kedua topik ini akan mempunyai hubungan yang saling mempengaruhi, dalam hal penegakan hukum yang dimaksud adalah implementasi pemberlakuan Kewarganegaraan Tunggal atau pemberlakuan DwiKewarganegaraan.

Langkah Indonesia melarang warganya untuk memiliki kewarganegaraan ganda adalah tepat, sebab aturan tersebut akan membuat setiap warga negara lebih loyal dalam mengabdikan diri kepada negara. Atau dapat juga dikatakan bahwa dalam konteks nasionalisme hal itu tidak tepat, sebab tidak mungkin seorang membelah diri, loyal di sana dan loyal di sini, demikian disampaikan oleh Margarito pakar hukum Tata Negara, saat berbincang dengan CNN Indonesia.com pada Selasa 16 Agustus 2016.

Langkah politik yang mengusulkan agar segera merevisi undang-undang tentang kewarganegaraan agar dapat 
mengakomodasi diaspora

Indonesia sebab banyak diaspora yang memiliki kompetensi mumpuni dan bisa diberdayakan di tanah air. Hal itu tentu harus dengan petimbangan politis juga sebab perlu melihat asas manfaat dan mudaratnya bagi negara Indonesia, sebagaimana dikemukakan oleh Hikmahanto yang meminta pemerintah mengkaji lebih mendalam dan hatihati menerapkan asas dewikewarganegaraan. Oleh karena itu pemerintah tidak harus tergesagesa merevisi undang-undang Nomor 12 tahun 2006 tentang Kewarganegaraan.

Sebagai kata akhir pernyataan pakar hukum internasional tersebut adalah "Orang kalau memang cinta tanah air, tidak harus memiliki dwi-kewarganegaraan. Mereka boleh berkewarganegaraan asing, tetapi kalau cinta tahan air lakukan apa saja yang bisa dilakukan".

\section{DAFTAR PUSTAKA}

\section{Buku:}

H.A. Prayitno, Trubus MS; Pendidikan KADEHAM, Kebangsaan, Demokrasi, dan Hak Asasi Manusia; hlm, 116.

Imam Syaukani; A. Ahsin Thohari; Dasar-

Dasar Politik Hukum, PT

Raji Grafindo Persada, Jakarta; hlm.5 - 8

Moh. Mahfud MD; Membangun Politik Hukum Mengegakkan Konstitusi; Rajawali Pers;

Divisi Buku Perguruan Tinggi, PT Raja Grafindo Persada, Jakarta 2012;

Satjipto Rahardjo, Ilmu Hukum; Alumni, Bandung; 1991, hlm 325; Melalui buku Imam Syaukani; A. Ahsin Thohari; Dasar-Dasar Politik Hukum, PT Raja Grafindo Persada, Jakarta; hlm.2.

Sudikno Mertokusumo; Penemuan Hukum Sebuah Pengantar, Yogyakarta: Liberty,.1999.

\section{Internett:}

http://mediaindonesia.com/news/read/6 2120/dwikewarganegaraan -bisa-untungkanindonesia/2016-08-18 
Politik Hukum Menegakkan Konstitusi, Tinjauan Status Dwi

Kewarganegaraan Berdasarkan Undang-Undang No. 12 Tahun 2006

https://id.wikipedia.org/wiki/Nasionalis me_Indonesia

http://mediaindonesia.com/news/read/6 2060/pakar-

dwikewarganegaraan-bisauntungkan-indonesia-

asalkan/2016-08-17.

http://mediaindonesia.com/editorial/read 1823/menimbang-revisi-uu kewarganegaraan /2016-0818; dalam acara PrimeTime News Metro TV, Rabu $(17 / 8 / 2016)$ malam.

Koransindo;

http://www.idartikel.com/ mahfud-

$\mathrm{md} / 2016 / 08 /$ politik-

hukum-dwi-warga-negara/ 